\title{
Immunological and Virological Outcomes at 5 Years in HIV Infected Adults Who Start HAART at a CD4 Cell Count of Less Than 200 in Barbados
}

\section{Alok Kumar ${ }^{1 *}$, Krishna R Kilaru ${ }^{2}$ and Timothy C Roach ${ }^{2}$}

${ }^{1}$ Faculty of Medical Sciences, University of the West Indies and the Queen Elizabeth Hospital, Barbados, West Indies ${ }^{2}$ Ladymeade Reference Unit, Ministry of Health, Government of Barbados, West Indies

\begin{abstract}
Objective: To assess the immunologic and virological response after 5 years of highly active antiretroviral therapy (HAART) in treatment naive HIV-1 infected adults presenting late in the course of their disease.

Design: Prospective long term observational study. The response to HAART is described in HIV-1 infected ARV naïve adults initiating treatment at CD4+ cell counts < 200 during June 2005 through December 2005 in Barbados, West Indies. Baseline values as well as 5 years post-HAART values for $\mathrm{CD} 4^{+}$cell counts and viral load were recorded for the cohort.

Results: 50 ARV naïve HIV-1 infected adults initiated treatment when their CD4+ cell count was, 200. Most received Combivir plus Nevirapine or Efavirenz. At the baseline, their median CD4+count was 36 cells/ $\mu \mathrm{L}$ (IQ Range:15-82) and their median viral load was at $75,000\left(4.87 \log _{10}\right)$ with an IQ Range of 52,700-226,000. After 5 years of therapy, the median increase in the CD4+ cell count was $122 \mathrm{cell} / \mu \mathrm{L}$ (IQ Range, 45-185). Twenty three (46\%) patients had achieved $\mathrm{CD}^{+}$cell counts of $\geq 200 \mathrm{cells} / \mathrm{\mu L}$. $36(72 \%)$ patients had an undetectable viral load $(<50 \mathrm{copies} / \mathrm{mL})$. The median decline in viral load at 5 years of therapy was $74,950\left(4.87 \log _{10}\right)$ copies $/ \mathrm{mL}$ with an IQ Range of 52,700 -226,000.
\end{abstract}

Conclusion: In this relatively small cohort of treatment naïve patients presenting late in the course of HIV disease, there was good immunological and virological response after 5 years of initiating HAART irrespective of their baseline $\mathrm{CD} 4^{+}$counts and viral load, age or gender.

Keywords: $\mathrm{CD}^{+}$cell count; HAART; Efficacy

\section{Introduction}

Highly active antiretroviral therapy (HAART) has significantly reduced morbidity and mortality in HIV-1 disease [1-3]. When to start HAART is one of the most important questions facing HIV-infected persons and their providers in nations that struggle with financing such therapies. To what extent delaying initiation of HAART may compromise its effectiveness remains unclear. There appears to be a consensus that HAART therapy should be initiated based primarily on a $\mathrm{CD}^{+}$count between 200 and 350 cells $/ \mathrm{mm}^{3}$ rather than viral load $[4,5]$. Results from a recently published multi-cohort study (ART Cohort study) which analyzed patients from Europe and North America have shown a clear benefit of initiation of HAART based on the $\mathrm{CD} 4^{+}$cell counts. The $\mathrm{CD}^{+}$cell count at initiation was the dominant prognostic factor in patients starting HAART [6]. However, the optimal CD4 ${ }^{+}$ count and appropriate timing within 200 and 350 cells $/ \mathrm{mm}^{3}$ remains unclear. Several studies have shown that the effectiveness of HAART is compromised in patients initiating therapy with $\mathrm{CD} 4^{+}$cell counts $<200$ cells $/ \mathrm{mm}^{3}$ [6-8]. Also there are evidence that delaying HAART until the time of severe immunosuppression $\left(<50\right.$ cells $\left./ \mathrm{mm}^{3}\right)$ is associated with higher mortality [9-11]. However some recent studies including some from the non-English speaking Caribbean have shown good efficacy of HAART even when started in patients with advanced HIV disease with $\mathrm{CD} 4^{+}$counts $<200$ cells/ $\mu \mathrm{L}[12-14]$. In a multicounty study in Africa has shown a high survival and immunological response rate in a large cohort of patients where majority had a CD4 cell count less than 200 [13].

In Barbados HAART has been made available for treatment of HIV infected individuals since 2003. However, the majority of HIV infected adults are diagnosed late in the course of their illness with low $\mathrm{CD} 4^{+}$ cell counts [15]. The aim of the study is to characterize immunological and virological responses when HAART is started at an advanced stage of the HIV infection with baseline $\mathrm{CD}^{+}$cell counts $<200$ cells $/ \mu \mathrm{L}$. In this first published report from the English Caribbean, we present the findings from a cohort of HIV infected persons who had low $\mathrm{CD} 4^{+}$cell counts at the time of their initial presentation and commencement of HAART and followed up for 5 years from the initiation of HAART.

\section{Methods}

The National HIV/AIDS referral and Treatment Centre (NHC) serves as the sentinel centre for HIV/AIDS management for the whole of Barbados. It is a specialist HIV/AIDS centre with a wide range of services including Voluntary Counselling and Testing (VCT), treatment including free antiretroviral medications and referral services, monitoring of treatment response with $\mathrm{CD}^{+}$cell counts and viral load analysis, follow up and supportive care of HIV infected persons. Major source of referral to this unit includes persons diagnosed to have HIV/ AIDS at the Queen Elizabeth Hospital, the only tertiary hospital on

*Corresponding author: Alok Kumar, Faculty of Medical Science, UWI (Queen Elizabeth Hospital) Martindales Road, St. Michael, Barbados, West Indies, Tel: 1 246 4366450; Fax: 1246429 5374; E-mail: alok.kumar@cavehill.uwi.edu

Received August 25, 2014; Accepted December 17, 2014; Published December 21,2014

Citation: Kumar A, Kilaru KR, Roach TC (2014) Immunological and Virological Outcomes at 5 Years in HIV Infected Adults Who Start HAART at a CD4 Cell Count of Less Than 200 in Barbados. J AIDS Clin Res 6: 406. doi:10.4172/2155 6113.1000406

Copyright: (C) 2014 Kumar A, et al. This is an open-access article distributed under the terms of the Creative Commons Attribution License, which permits unrestricted use, distribution, and reproduction in any medium, provided the original author and source are credited. 
the island. Other source of referral includes the state run polyclinics that serve as the primary health care provider and private General Practitioners. Persons may get tested for medical illnesses suspected to be due to HIV infection, during antenatal screening, for presenting with sexually transmitted diseases, by way of voluntary counselling and testing or tested for other reasons. Persons may also present to the NHC either for VCT or when one of their sex partners is diagnosed with HIV infection.

\section{Patient population}

The patient population for this study were taken from a cohort of HIV infected patients attending the NHC and being followed up by the authors. The study includes all the HIV-1 infected adults who initiated treatment at NHC during June 2005 through December 2005 and who had a CD $4^{+}$cell counts $<200$ at the time of initiation of HAART. These patients were followed up for 5 years.

\section{Treatment protocol}

HAART has been provided at no cost to all HIV-infected individuals in need of treatment in this country based on the Caribbean guidelines on treatment and follow up of the HIV/AIDS. This guideline recommends initiation of treatment (HAART) for patients with significant or AIDS-defining symptoms, regardless of $\mathrm{CD}^{+} \mathrm{T}$ cell count or HIV viral load. Initiation of HAART is also recommended for asymptomatic patients with a CD4 ${ }^{+} \mathrm{T}$ cell count of $<200 \mathrm{cells} / \mathrm{mm}^{3}$. For asymptomatic patients with a CD4 ${ }^{+} \mathrm{T}$ cell count between 200 and 350 cells $/ \mathrm{mm}^{3}$, HAART should generally be offered, recognising that a better response to HAART is likely if treatment is initiated before the $\mathrm{CD}^{+} \mathrm{T}$ cell count falls to $<200$ cells $/ \mathrm{mm}^{3}[16]$.

Since 2002, all 3 classes of antiretroviral agents [nucleoside reverse transcriptase inhibitors (NRTI), protease inhibitors (PI) and nonnucleoside reverse transcriptase inhibitors (NNRTI)] have been available at NHC. The current Caribbean guidelines advocates the advantages of an NNRTI-based initial HAART regimen and Efavirenz or Nevirapine is the preferred drug based on good tolerability and efficacy [16]. In cases with severe anaemia Zidovudine was replaced by Stavudine. All the patients with the baseline $\mathrm{CD} 4^{+}$cell counts $<200$ were placed on Cotrimoxazole for PCP prophylaxis. All patients had a treatment preparedness counselling session with the resident counsellor prior to commencing the HAART therapy which included assessment of the social support available to the patient and education about the treatment requirements and adherence.

\section{Patient visits}

For all patients in the study, a complete prospective profile of antiretroviral therapy was maintained, including the medications prescribed, the amount dispensed, the dose, and the prescriptionfill dates along with other information on socio-demographic characteristics, clinical and health status, elicited at the time of initial enrolment. Adherence was recorded on each visit using the pill count method. Before the initiation of HAART, patients had the following laboratory tests-full blood counts including hemoglobin level; renal function tests including serum electrolytes; liver function tests; screening tests for other sexually transmitted infections such as Hepatitis B and C, VDRL for syphilis and HTLV infection; $\mathrm{CD} 4^{+}$cell counts and Viral load. Patients were also screened for active OI's such as tuberculosis.

\section{Statistical analysis}

Intent to treat approach was taken for analysis. We used a combination of uni-variate parametric and non-parametric analyses. All $\mathrm{p}$-values were two tailed and values less than 0.05 was considered significant. All analysis was performed using the statistical package SPSS version 10. Mean changes in $\mathrm{CD}_{4}^{+}$cell counts and percentage of patients with undetectable viral load (the dependent variables) were compared against the age, gender, base line $\mathrm{CD}^{+}$cell counts and base line viral load (independent variables). Immunologic response was defined as an increase in $\mathrm{CD} 4^{+}$cell count from baseline of more than 50 cells $/ \mu \mathrm{L}$ on their last $\mathrm{CD} 4^{+}$cell count. Virological response was defined as a decrease in plasma HIV RNA level from baseline of more than 1 $\log _{10}$ copies/mL or a plasma HIV RNA level less than 1,000 copies $/ \mathrm{mL}$ on the last viral load estimation. Virological success was defined as a decrease in plasma HIV RNA level from baseline to undetectable viral load of less than 50 copies $/ \mathrm{mL}$ on their last viral load estimation.

\section{Results}

From June 2005 through December 2005, a total of 79 patients were started on HAART, of which 56 patients had $\mathrm{CD}^{+}$cell counts $<200$ cells $/ \mu \mathrm{L} .4$ patients died prior to starting HAART and 2 other patients were excluded from the analysis as they defaulted immediately from the follow up after initiating HAART. Therefore the remaining 50 patients for whom HAART was initiated during the June 2005 through December 2005 were analyzed for this report.

\section{Treatment regimens}

As per the guidelines; most patients (42 patients, $84 \%$ ) initiated on NNNRTI based HAART using Zidovudine and Lamivudine plus either Nevirapine (8 patients, 16\%) or Efavirenz (34 patients, $68 \%$ ). A few (2 patients, 4\%) started on Stavudine and Lamivudine plus Nevirapine. The remaining 6 patients were initiated on PI based triple regimen - Zidovudine and Lamivudine plus Indinavir (5 patients, 10\%) or Nelfinavir (1 patient, 2\%). Cost effectiveness, availability of medicine and any existing co-morbid conditions were the criteria used for selecting a particular regimen. All of the patients had a Co-trimoxazole prophylaxis at some point during the study period. The duration of Cotrimoxazole in the individual patients varied between 22 months and 70 months (Mean 38.6 months, Median 30 months).

\section{Baseline characteristics}

Baseline characteristics of the study subjects are shown in Table 1. The median age of patients in the cohort was 40 years (Range, 2066 years); $34.2 \%$ females. At baseline most had advance disease, as

\begin{tabular}{|c|c|}
\hline Characteristics Cohort $n=50$ & Numbers \\
\hline Patients & $32(64 \%)$ \\
\hline Female & $18(36 \%)$ \\
\hline Age group & $18(36 \%)$ \\
\hline $36-45$ & $17(34 \%)$ \\
\hline$>45$ & $15(30 \%)$ \\
\hline Median Age (Range) & $40(22-66)$ \\
\hline \multicolumn{2}{|l|}{$\mathrm{CD}^{+}$cell counts $(n=45)$} \\
\hline$<50$ cells $/ \mathrm{L}$ & $26(57.8 \%)$ \\
\hline$\geq 50$ cells $/ \mu \mathrm{L}$ & $19(42.2 \%)$ \\
\hline Median CD4 ${ }^{+}$counts (IQRange) & $36(15-82)$ \\
\hline \multicolumn{2}{|l|}{ Plasma HIV RNA load (n=35) } \\
\hline$<100,000$ & $20(57.1 \%)$ \\
\hline$\geq 100,000$ & $15(42.9 \%)$ \\
\hline Median Plasma HIV RNA (IQR) & $75,000(52,700-226,000)$ \\
\hline
\end{tabular}

Table 1: Baseline characteristics of the 50 ARV naïve adults who initiated HAART at $\mathrm{CD} 4^{+}$cell counts $<200$. 
evidenced by their low median $\mathrm{CD}^{+}$cell counts of 36 cells $/ \mu \mathrm{L}$ (IQ Range, 15-82); and their median viral load of 75,000 copies $/ \mathrm{mL}$ (4.87 $\log _{10}$ copies/ml) with an IQ Range of 52700-226000 at the baseline.

\section{Follow up and retention}

The median duration of follow up for this cohort (50 patients) was 70 months. Three patients died within 3 months of initiating HAART and no follow up $\mathrm{CD} 4^{+}$cell counts or viral loads were available. Three more persons died during the 5 year follow up and two persons were lost for follow up since they left the island and moved to their country of origin leaving 42 for follow up at endpoint 5 years. Overall average adherence for the individual patients in this cohort during the 5 years follow up was between $72.6 \%$ and $96.7 \%$ (Mean $86.3 \%$ ).

\section{Response to treatment}

At 5 years after initiating HAART (Table 2), for the 42 patients available for follow up the median $\mathrm{CD}^{+}$count was 199 cells/ $\mu \mathrm{L}$ (IQ Range, $116-240 / \mu \mathrm{L}$ ). The median increase from baseline was 122 cells/ $\mu \mathrm{L}$ (IQ Range, 45-185) and this constituted an over three-fold rise in the median $\mathrm{CD}^{+}$cell counts from the baseline. There were 39 (78\%) has immunologic response (an increase in the CD4 cell count of over 50 cell $/ \mu \mathrm{L}$ on the last CD4 counts). Twenty three (46\%) patients had achieved $\mathrm{CD} 4{ }^{+}$cell counts of $\geq 200$ cells $/ \mu \mathrm{L}$ on their last CD 4 cell count done within six months of this report. The median decrease in viral load from baseline was 74,950 copies/mL (4.87 $\log _{10}$ copies $\left./ \mathrm{mL}\right)$ with an IQ Range of 52,650-244,950 copies/ml. There were $41(80 \%)$ had virological response (viral load $<1000$ copies/ml). Thirty six $(72 \%)$ patients had achieved an undetectable viral load $(<50$ copies $/ \mathrm{mL})$ on their last viral load measurement done within six months of this report (Table 2). There were 37 (74\%) patients who had both immunological and virological response and $2(4 \%)$ patients had only immunological response and $4(8 \%)$ showed only virological response $(\mathrm{P}=0.072)$.

Of the 26 patients who initially had a $\mathrm{CD}^{+}$cell counts of $<50$ cells/ $\mu \mathrm{L}, 23(88.5 \%)$ achieved immunological response and $24(92.3 \%)$ achieved virological response whereas 15 (78.9\%) out of the 19 patients with $\mathrm{CD}^{+}$cell counts between 50 and 200 cells/ $\mu \mathrm{L}$ achieved immunological response and 17 (89.5\%) achieved virological response at 5 years $(\mathrm{P}=0.267)$. On univariate analysis, there was no significant $(\mathrm{P}=0.152)$ difference among those who achieved immunological and virological success in terms of age or sex of the patients. There was no significant $(\mathrm{P}=0.062)$ difference in the response based on the type of HAART regimen used. The Mean of the adherence of individual patients in those with a CD4 cell counts was $92.8 \%$ whereas the Mean of the adherence of individual patients in group with a CD4 cell counts $\geq 50$ was $81.5 \%(\mathrm{P}=0.012)$.

None of these patients had major drug toxicity to necessitate discontinuation of their HAART. However, 1 patient on Nevirapine had transient increase in the liver enzyme ALT (more than two fold rises) and AST (more than two fold rise). Among minor toxicities, Gastro-

\begin{tabular}{|c|c|}
\hline Response parameters & Values \\
\hline Median CD4+ counts- cells/ $\mu \mathrm{L}$ (IQ Range) & $199(117-240)$ \\
\hline Median increase in $\mathrm{CD}^{+}$counts from baseline - cells $/ \mu \mathrm{L}(\mathrm{IQR})$ & $122(45-185)$ \\
\hline Patients with $\mathrm{CD}^{+}>200$ cells $/ \mu \mathrm{L}$ & $23(46.0 \%)$ \\
\hline $\begin{array}{l}\text { Median decrease in plasma RNA viral load from baseline- } \\
\text { copies/ml } \\
\text { Inter Quartile Range }\end{array}$ & $\begin{array}{c}74,950\left(4.87 \log _{10}\right) \\
52,650-244,950\end{array}$ \\
\hline Patients with plasma RNA viral load $<50$ copies $/ \mathrm{mL}$ & $36(76.6 \%)$ \\
\hline
\end{tabular}

Table 2: Response to HAART after 5 years of therapy among the 42 ARV naïve adults available for follow up. intestinal toxicity in the form of nausea and gastritis along with skin rash were common short term problems. Central redistribution of fat was seen in 3 persons, all three were on PI based regimens. 26(52\%) were on their second regimens and $11(22 \%)$ were on their third regimen.

Overall mortality rate for this cohort was $12 \%$, all 3 patients died within three months of initiating HAART whereas 3 others dies during the 5 year follow up period. In all these 6 persons death was attributed directly or indirectly to their HIV infection. Opportunistic infection was listed as one of the causes of death in all 6 patients. Neurotoxoplasmosis in in 3 patients, oropharyngeal candidiasis in 2 patients and Pneumocystis jiroveci pneumonia in one where it was the direct cause for death. Serious Bacterial infection was listed as cause of death in 3 patients, all these three patients had renal failure as well and serious bacterial infection (sepsis in 2 and pneumonia in one) was stated to be the direct cause of death.

\section{Discussion}

Our study cohort of $50 \mathrm{HIV}$-infected treatment naïve patients with severe immunosuppression $\left(\mathrm{CD}^{+}\right.$cell counts $<200$ cells $\left./ \mu \mathrm{L}\right)$ showed a high rate of immunological and virological response to HAART and a high proportion of these patients had undetectable $(<50$ copies $/ \mathrm{mL})$ viral load after 5 years of therapy. After 5 years of HAART, we observed an over three fold rise in the median $\mathrm{CD}^{+}$cell counts from the baseline. Rise in the $\mathrm{CD} 4^{+}$cell counts was evenly distributed across the range of CD4 cell count. Half of all the patients achieved $\mathrm{CD} 4^{+}$cell counts of $\geq$ 200 cells $/ \mu \mathrm{L}$. Of the remaining half, all but three had $\mathrm{CD} 4^{+}$cell count in the range of 150 to 200 cells/ $\mu \mathrm{L}$. Very similar observations have been made in recent reports from Botswana $[9,12,13]$. These observations are interesting and very revealing against the background of widely held consensus that therapy should be initiated at $\mathrm{CD} 4^{+}$counts between 200 and 350 cells $/ \mu \mathrm{L}$ [4-8]. It has significant implications for resource limited settings where delay in initiating therapy is very common.

The rate of immunological and virological success 5 years postHAART initiation in this cohort was quite impressive. Over threefourths of these patients achieved both the immunological and virological success. There was no significant $(\mathrm{P}=0.072)$ discordance between the immunological and virological response. Our rate of success was similar to those reported in studies from the developed countries [17-19]. After univariate analysis we found no significant differences $(\mathrm{P}=0.062)$ between those who achieved immunological response and those who did not, in terms of the response rate based on the age or sex of the study cohort. However, the small sample size was a major limitation and may have resulted in a type II error causing a failure to show a statistically significant difference. Response to HAART being independent of age and sex has been reported in other studies as well [18-20]. It was interesting to note that the response rate among those with CD 4 cell counts $<50$ cells $/ \mu \mathrm{L}$ was marginally better than those with a CD4 cell counts $\geq 50$ cells $/ \mu \mathrm{L}$. However, this was statistically not significant $(\mathrm{P}=0.267)$. This difference may have resulted from better adherence (Mean adherence 92.8\%) level among the sub group of patients with $\mathrm{CD} 4^{+}$counts $<50$ cells $/ \mu \mathrm{L}$ when compared to the sub group with $\mathrm{CD} 4^{+}$counts between 50 through 199 cells/ $\mu \mathrm{L}$ (Mean adherence $81.5 \%$ ). Also because of the small number which limited statistical power and analysis, there was no significant difference in the response based on the type of HAART regimen used.

The findings from this study show that HAART is effective, even when started late in the course of the HIV infection. These findings have major implications for Barbados as well as for the other developing countries in the Caribbean where patients are often diagnosed late 
in the course of HIV disease and resources are limited [15]. It will be useful to study the response to HAART in larger cohort of patients starting HAART at low $\mathrm{CD} 4^{+}$cell counts with a well matched control of patients starting HAART at higher $\mathrm{CD} 4^{+}$cell counts. Our own cohort has grown larger in number over time since this preliminary report and it may allow us more rigorous analysis and robust conclusions in the future. A major limitation of this study was the small sample size. If these responses to HAART in HIV infected patients with low $\mathrm{CD} 4^{+}$cell counts with similarly high degree of concordance between the immunological and virological response can be duplicated in larger cohorts then these results could have major impact on the treatment of HIV infected persons in middle and low income countries.

\section{References}

1. Hammer SM, Squires KE, Hughes MD, Grimes JM, Demeter LM, et al. (1997) A controlled trial of two nucleoside analogues plus Indinavir in persons with human immunodeficiency virus infection and $\mathrm{CD} 4^{+}$cell counts of 200 per cubic millimeter or less. AIDS Clinical Trials Group 320 Study Team. N Engl J Med 337: 725-733.

2. Mocroft A, Vella S, Benfield TL, Chiesi A, Miller V, et al. (1998) Changing patterns of mortality across Europe in patients infected with HIV-1. EuroSIDA Study. Lancet 352: 1725-1730.

3. Palella FJ Jr, Delaney KM, Moorman AC, Loveless MO, Fuhrer J, et al. (1998) Declining morbidity and mortality among patients with advanced human immunodeficiency virus infection. HIV Outpatient Study Investigators. N Engl J Med 338: 853-860.

4. Opravil M, Ledergerber B, Furrer H, Hirschel B, Imhof A, et al. (2002) Swiss HIV Cohort Study Clinical efficacy of early initiation of HAART in patients with asymptomatic HIV infection and $\mathrm{CD}^{+}$cell count $>350 \times 10(6) /$. AIDS 16 :1371-1381.

5. Sterne JA, May M (2009) When to Start Consortium Timing of initiation of antiretroviral therapy in AIDS-free HIV-1-infected patients: a collaborative analysis of 18 HIV cohort studies. TheLancet 373:1352 - 1363.

6. Egger M, May M, Chene G, Phillips AN, Ledergerber B, et al. (2002) ART Cohort Collaboration. Prognosis of HIV-1-infected patients starting highly active antiretroviral therapy: a collaborative analysis of prospective studies. Lancet 360: $119-129$.

7. Hogg RS, Yip B, Wood E, Chan K, Craib KJP, et al. (2001) Montaner. Diminished Effectiveness of Antiretroviral Therapy among Patients Initiating Therapy with CD4 ${ }^{+}$Cell Counts Below 200/ $\mathrm{mm}^{3}$. 8th Conference on Retroviruses and Opportunistic Infections February 4-8.

8. Kaplan J, Hanson D, Karon $\mathrm{J}(2001)$ Late initiation of antiretroviral therapy (at $\mathrm{CD} 4^{+}$lymphocyte count $<200$ cells $/ \mathrm{mL}$ ) is associated with increased risk of death.From: 8th Conference on Retroviruses and Opportunistic Infections February 4-8, 2001; Chicago, III. Abstract 520.

9. Wester CW, Kim S, Bussmann H, Avalos A, Ndwapi N, et al. (2005) Initia response to highly active antiretroviral therapy in HIV-1C-infected adults in a public sector treatment program in Botswana. J Acquir Immune Defic Syndr 40: 336-343.

10. Miller V, Phillips AN, Clotet B, Mocroft A, Ledergerber B, et al. (2002)Association of virus load, $\mathrm{CD} 4^{+}$cell count, and treatment with clinical progression in human immunodeficiency virus-infected patients with very low $\mathrm{CD} 4{ }^{+}$cell counts. J Infect Dis 186: 189-197.

11. MacArthur RD, Perez G, Walmsley S, Baxter JD, Mullin CM, et al. (2005) Community Programs for Clinical Research on AIDS (CPCRA) 042/045 Canadian HIV Trials Network (CTN) 102 Protocol Teams. Comparison of prognostic importance of latest $\mathrm{CD}^{+}$cell count and HIV RNA levels in patients with advanced HIV infection on highly active antiretroviral therapy. HIV Clin Trials 6: 127-135.

12. Clarke TR, Barrow G, Thompson D, Gibson R, Barton EN (2010) Response to first line HAART using CD4 cell counts: experience in a University Hospital in Kingston. West Indian med J 59: 439-444.

13. Van der Borght SF, Clevenbergh P, Rijckborst H, Nsalou P, Ngozi O (2009) Mortality and morbidity among HIV type-1-infected patients during the 5 years of multicountry HIV workplace programme in Africa. Antiviral Theapy 14: 63-74.

14. Andrew N, Phillips, Schlomo Staszewski, Rainer Weber, Ole Kirk, et al. (2001) for the Swiss HIV Cohort Study, the Frankfurt HIV Clinic Cohort, and the EuroSIDA Study Group. HIV viral load response to antiretroviral therapy according to the baseline CD4 ${ }^{+}$cell count and viral load. JAMA 286: 2560-2567.

15. Kilaru KR, Kumar A, Roach T, Abayomi A, Sippy N, et al. (2004) CD4+ Cell counts in adults with newly diagnosed HIV infection in Barbados.Pan-American Journal of Public Health 16: 718-725

16. CHART (2005) Caribbean Guidelines for the Care and Treatment of Persons with HIV Infection.

17. Grabar S, Le Moing V, Goujard C (2000) Clinical outcome of patients with HIV1 infection according to immunologic and virologic response after 6 months of highly active antiretroviral therapy. Ann Intern Med 133: 401-410.

18. Danel C, Moh R, Anzian A, Abo Y, Chenal H, et al. (2006) Tolerance and acceptability of an efavirenz-based regimen in 740 adults (predominantly women) in West Africa. J Acquir Immune Defic Syndr. 42: 29-35.

19. Erb P, Battegay M, Zimmerli W, Rickenbach M, Egger M (2000) Effect of antiretroviral therapy on viral load, $\mathrm{CD}^{+}$cell count, and progression to acquired immunodeficiency syndrome in a community human immunodeficiency virusinfected cohort. Swiss HIV Cohort Study. Arch Intern Med 160:1134-1140.

20. Moore AL, Kirk O, Johnson AM, Katlama C, Blaxhult A, et al. (2003) Virologic, immunologic, and clinical response to highly active antiretroviral therapy: the gender issue revisited. EuroSIDA group. J Acquir Immune Defic Syndr 32: 452461. 